\title{
Targeted Protein Degradation via a Covalent Reversible Degrader Based
}

\section{on Bardoxolone}

\author{
Bingqi Tong,\#, a,b Mai Luo,\#, a,b Yi Xie, ${ }^{a, b}$ Jessica N. Spradlin, ${ }^{a, b}$ John A. Tallarico, ${ }^{b, c}$ Jeffrey M. \\ McKenna, ${ }^{b, c}$ Markus Schirle, ${ }^{b, c}$ Thomas J. Maimone, ${ }^{*, a, b}$ and Daniel K. Nomura*a,b,c,
}

\begin{abstract}
Targeted protein degradation (TPD) has emerged as a powerful tool in drug discovery for the perturbation of protein levels using heterobifunctional small molecules (i.e. PROTACs). E3 ligase recruiters remain central to this process yet relatively few have been identified relative to the $>500$ predicted human E3 ligases. While, initial recruiters have utilized non-covalent chemistry for protein binding, very recently covalent engagement to novel E3's has proven fruitful in TPD application. Herein we demonstrate efficient proteasome-mediated degradation of BRD4 by a bifunctional small molecule linking the KEAP1-NRF2 activator bardoxolone to a BRD4 inhibitor JQ1. Notably, this work reports the first covalent, reversible E3 ligase recruiter for TPD applications.
\end{abstract}

Targeted protein degradation (TPD) has emerged as a powerful therapeutic modality for drug discovery. ${ }^{[1]}$ One strategy available to achieve this therapeutic modality employs heterobifunctional small-molecules known as degraders or proteolysis-targeting chimeras (PROTACs) that are comprised of three constitutive components: a E3 ligase recruiter; a linker; and a ligand to target a protein of interest (POI). By recruiting the E3 ligase to the $\mathrm{POI}$, the resultant PROTAC is able to induce ubiquitination and degradation of the $\mathrm{POI}$ in a proteasomedependent manner (Figure $1 \mathrm{~A}){ }^{[1]}$ While this therapeutic modality has tremendous potential, a major challenge overshadowing the area is that there are only a small number of E3 ligase recruiters that have been identified, this despite there being in excess of 600 predicted E3 ligases. The known E3 ligase recruiters include thalidomide-type immunomodulatory drugs (IMiDs) that recruit cereblon (CRBN), hydroxyproline-based ligands for the vonHippel Lindau (VHL) E3 ligase, nutlins that bind to MDM2, and ligands against CIAP (Figure 1B) ${ }^{[1-5]}$. While these recruiters bind reversibly to their corresponding $\mathrm{E} 3$ ligases recent studies have revealed that covalent small-molecules can also be used as E3 ligase recruiting modules to potently degrade target proteins in TPD applications. These Figure 1. (A) Targeted protein degradation

[a] Department of Chemistry University of California, Berkeley Berkeley, CA, 94720, USA

E-mail: maimone@berkeley.edu.

[b] Novartis-Berkeley Center for Proteomics and Chemistry Technologies

[c] Novartis Institutes for BioMedical Research Cambridge, MA, 02139, USA

[d] Departments of Molecular and Cell Biology, and Nutritional Sciences and Toxicology Berkeley, CA 94720, USA e-mail: dnomura@berkeley.edu

* co-corresponding authors

\# these authors contributed equally

Supporting information for this article is given via a link at the end of the document.

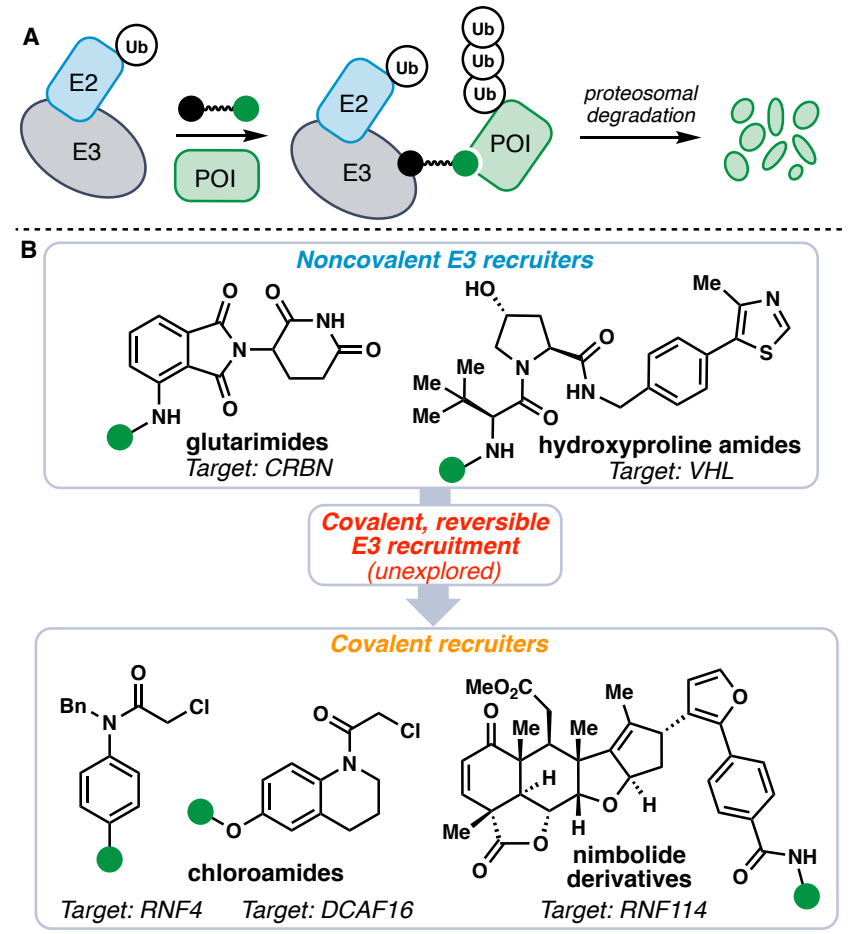

using bifunctional small molecules. (B) Selected examples of E3 ligase recruiters of varying degrees of covalent engagement.

electrophilic moieties include derivatives of the terpene natural product nimbolide that covalently binds to a disordered cysteine on the E3 ligase RNF114, CCW16 that reacts with a zinccoordinating cysteine on the E3 ligase RNF4, and KB02 that covalently targets the cullin E3 ligase DCAF16 (Figure 1B) ${ }^{[6-8]}$.

Based on the success of covalent E3 ligase recruiters, we postulated that covalent and reversible E3 ligase recruitment could be a third, underexplored area in PROTAC development (Figure 1B). As a possible mechanism of action, reversible covalent modification offers the potential for sustained target engagement, while avoiding permanent protein modification - a feature of particular interest given the catalytic nature of PROTACs. While this concept has proven powerful in drug discovery settings, ${ }^{[9,10]}$ we are unaware of its successful employment in E3 ligase recruitment. Herein we report a potent protein degrader exploring this concept. ${ }^{[11]}$

We were intrigued by the possibility of exploiting the triterpene derivative bardoxolone methyl (CDDO-Me) as a covalent, reversible ligase recruiter owing to its reversible interactions with cysteines on the E3 ligase KEAP1 and its highly electron-deficient cyanoenone moiety. ${ }^{[12]}$ To test this hypothesis, whether bardoxolone could be used as a novel E3 ligase recruiter, we synthesized a bardoxolone-based PROTAC by linking bardoxolone to the BET family bromodomain protein inhibitor JQ1 (see CDDO-JQ1 (1), Figure 2A). 


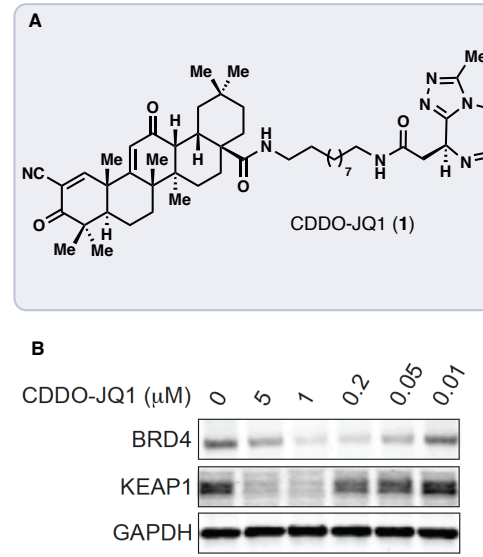

GAPDH

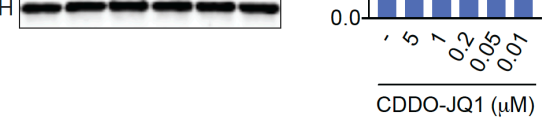

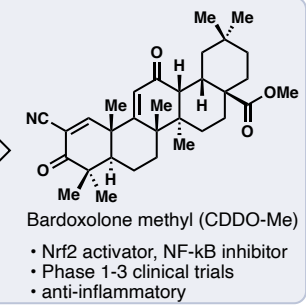

BRD4 levels

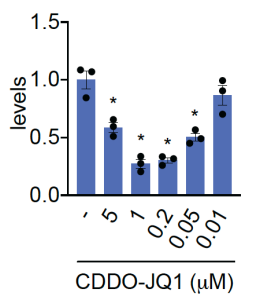

KEAP1 levels

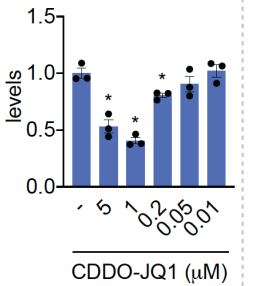

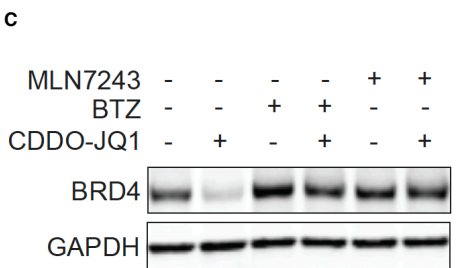

BRD4 levels

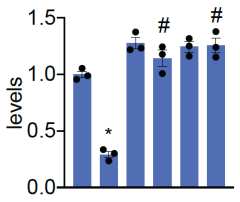

CDDO-JQ1 - + - + - +

$\mathrm{BTZ}-\ldots++\cdots$

MLN7243 - - - + +

BRD4 levels

Figure 2. Bardoxolone-based protein degradation. (A) Structure of a CDDO-JQ1 degrader. B) Effect of CDDO-JQ1 on BRD4 and KEAP1 levels in 231MFP cells treated with DMSO vehicle or CDDO-JQ1 for $12 \mathrm{~h}$, assessed by Western blotting. (C) BRD4 levels in $231 \mathrm{MFP}$ cells pre-treated with vehicle, proteasome inhibitor bortezomib $(1 \mu \mathrm{M})$, or E1 activating enzyme inhibitor MLN7243 $(1 \mu \mathrm{M})$ for 30 min prior to treatment with vehicle or CDDO-JQ1 (200 $\mathrm{nM}$ ) for $12 \mathrm{~h}$. (D) BRD4 levels in 231MFP cells pre-treated with DMSO vehicle or NEDD8 inhibitor MLN4924 (1 $\mu \mathrm{M}$ ) for 30 min prior to treatment with DMSO vehicle or CDDO-JQ1 $(200 \mathrm{nM})$ for $12 \mathrm{~h}$. Blots are representative of $\mathrm{n}=3$ biological replicates/group. Data in bar graphs is expressed as individual replicate values and average \pm sem. Significance shown as ${ }^{*} p<0.05$ compared to vehicle-treated control groups and \#p<0.05 compared to CDDO-JQ1treated groups.

We tested CDDO-JQ1 in the 231MFP human breast cancer cell line and demonstrated dose-responsive degradation of BRD4. though as expected with a heterobifunctional degrader, we observed loss of BRD4 degradation at higher concentrations due to the "hook" effect, indicating non-productive binary interactions with either the E3 ligase or BRD4 (Figure 2B). Interestingly, we also observed loss of KEAP1 at higher concentrations in cells treated with CDDO-JQ1, a phenomenon that has been reported previously by treating cells with electrophilic stressors (Figure 2B). ${ }^{[13]}$ Notably extensive degradation of BRD4 was observed in the 100-200 nM range without any optimization of linker length or

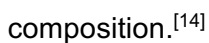

We further demonstrated that the CDDO-JQ1 mediated degradation of BRD4 was attenuated by pre-treatment with the proteasome inhibitor bortezomib as well as the E1 activating enzyme inhibitor MLN7243 (Figure 2C). Given that KEAP1 belongs to the CUL3 family of E3 ligases that require NEDDylation for activity, we further demonstrated that the BRD4 degradation conferred by CDDO-JQ1 was also significantly attenuated by the Nedd8 activating enzyme inhibitor MLN4924 (Figure 2D).

To show that the observed degradation by CDDO-JQ1 was not due to hydrophobic tagging of BRD4 leading to local protein unfolding and subsequent ubiquitination and degradation, ${ }^{[15]}$ we synthesized two negative control compounds, both having significantly altered electrophilicity and resultant covalent protein reactivity, but crucially having similar physicochemical properties (Figure 3A). Removal of the cyanoenone moiety by hydrogenation ultimately produced $\mathrm{H}_{2}$-CDDO-JQ1 as a mixture of diastereomers and enol tautomers (see SI for synthetic details). Importantly, $\mathrm{H}_{2}$-CDDO-JQ1 did not induce BRD4 degradation in comparison to CDDO-JQ1 exemplifying the criticality of this functional group (Figure 3B).
A

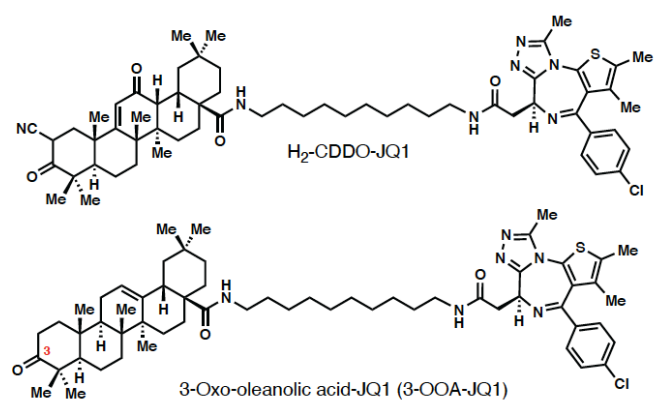

B

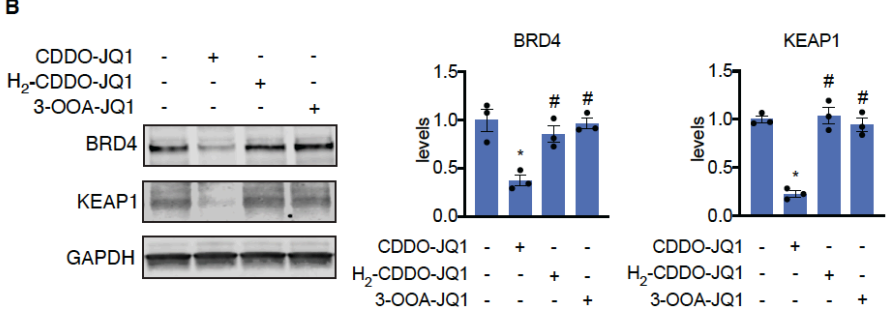

Figure 3. Unreactive negative control degraders do not degrade BRD4. (A) Structures of unreactive negative control degraders $\mathrm{H}_{2}$-CDDO-JQ1, and 3-oxo-oleanoic acid-JQ1. (B) Effect of CDDO-JQ1, $\mathrm{H}_{2}$-CDDO-JQ1, and 3-oxo-oleanoic acid-JQ1 degraders on BRD4 and KEAP1 levels in $231 \mathrm{MFP}$ cells assessed by Western blotting. DMSO vehicle or compounds were treated at $1 \mu \mathrm{M}$ for $12 \mathrm{~h}$. Blots are representative of $n=3$ biological replicates/group. Data in bar graphs is expressed as individual replicate values and average \pm sem. Significance shown as ${ }^{*} p<0.05$ compared to vehicle-treated control groups and \#p<0.05 compared to CDDO-JQ1treated groups. 
Similarly, treatment with the related bifunctional compound based on 3-oxo-oleanolic acid, namely 3-Oxo-oleanolic acid-JQ1 (3-OOA-JQ1), which possesses no potentially reactive alkenes of any type, also did not lead to BRD4 degradation. Notably, both of these structural changes were known to reduce Nrf2 activation in the medicinal chemistry campaigns involving bardoxolone methyl as an anti-inflammatory drug. ${ }^{[12]}$ Nevertheless a number of questions remain: firstly, CDDO does not bind the Kelch domain of the KEAP1/Cul3 complex, the key area for recognition of Nrf2 and where degrader, ${ }^{[16]}$ and multiple small molecule inhibitors presumably bind. ${ }^{[17-20]}$ This raises the question how (or if) a CDDO-based PROTAC can mechanistically induce neosubstrate degradation in a KEAP1-dependent manner. Secondly, while bardoxolone is thought to activate Nrf2 through the targeting of reactive cysteines on KEAP1, it also possess additional pharmacologic targets, including IKKB which modulates NF-KB signaling. ${ }^{[21]}$ It should be noted that the direct detection of all proteome-wide targets of CDDO by pulldown studies has proven challenging given the highly reversible nature of its cysteine interactions. ${ }^{[12 c, 22-23]}$ Thus, we cannot rule out at this moment that the degradation observed here may be due to one (or more) other cullin-family E3 ligases that are targeted by CDDO-JQ1.

In conclusion, the combined results summarized in Figure 2, together with the data from the two modified CDDO analog based degraders strongly implicate E3 ligase involvement and covalent cysteine reactivity in the mechanism of BRD4 degradation by CDDO-JQ1. Emerging evidence suggests that clinical resistance to PROTACs can occur through rewiring of the cellular E3 ligase machinery, ${ }^{[24]}$ thus highlighting the critical need for more and diverse E3 ligase recruiters. Single bifunctional compounds which can degrade proteins through multiple E3 ligases are particularly intriguing. Chemoproteomic and genetic efforts to map the proteome-wide targets of CDDO-JQ1 in cells is underway and will be reported in due course.

\section{Acknowledgements}

We thank the members of the Nomura Research Group, the Maimone lab, and the Novartis Institutes for BioMedical Research for critical reading of the manuscript. We are grateful to Dr. Hasan Celik for NMR spectroscopic assistance and NIH grant S10OD024998. This work was supported by the Novartis Institutes for BioMedical Research, the Novartis-Berkeley Center for Proteomics and Chemistry Technologies, the Mark Foundation for Cancer Research ASPIRE award, and NIH (R01CA240981, F31CA239327).

Competing Financial Interests Statement. JAT, JMM, MS are employees of Novartis Institutes for BioMedical Research. This study was funded by the Novartis Institutes for BioMedical Research and the Novartis-Berkeley Center for Proteomics and Chemistry Technologies. DKN is a co-founder, shareholder, and adviser for Artris Therapeutic and Frontier Medicines.

Keywords: CDDO, bardoxolone methyl, KEAP1, Nrf2, PROTAC, degrader, targeted protein degradation, E3 ligase, cysteine, BRD4

2013, 135, 5298; c) J. M. Bradshaw et. al. Nat. Chem. Biol. $2015,11,525$.

[10] For discussions on this topic, see: a) A. Bandyopadhyay, J. Gao, Curr. Opin.Chem. Biol. 2016, 34, 110; b) E. H. Krenske, R. C. Petter, K. N. Houk, J. Org. Chem. 2016, 81, 11726; c) A. Tuley, W. Fast, Biochemistry 2018, 57, 3326; d) P. A. Jackson, J. C. Widen, D. A. Harki, K. M. Brummond, J. Med. Chem. 2017, 60, 839.

[11] For recent PROTACs employing covalent, reversible chemistry on the non-E3 ligase targeting side, see: a) W.-H. Guo et. al. Biorxiv, doi: https://doi.org/10.1101/2019.12.30.873588; b) R. Gabizon et. al.Chemrxiv, https://doi.org/10.26434/chemrxiv.11494398.v2.

[12] a) M. S. Yates et. al. Mol. Cancer Ther. 2007, 6, 154; b) K. T. Liby, M. B. Sporn, Pharmacolog. Rev. 2012, 64, 972; c) M. B. Sporn, K. T. Liby, M. M. Yore, L. Fu, J. M. Lopchuk, G. W. Gribble, J. Nat. Prod. 2011, 74, 537.

[13] K. Taguchi et. al. Proc. Natl. Acad. Sci. 2012, 109, 13561.

[14] H. J. Maple, N. Clayden, A. Baron, C. Stacey, R. Felix, 2019 Med. Chem. Commun., 2019, 10, 1755.

[15] a) T. K. Neklesa et al. Nat. Chem. Biol. 2011, 7, 538; b) H. S. Tae et. al. ChemBioChem. 2012, 13, 538; c) G. V. Los et. al. ACS Chem Biol. 2008, 3, 373; d) M. J. C. Long, D. R. Gollapalli, L. Hedstrom, Chem. Biol. 2012, 19, 629; e) J. L. Gustafson et. al. Angew. Chem. Int. Ed.

[16] M. Lu, T. Liu, Q. Jiao, J. Ji, M. Tao, Y. Liu, Q. You, Z. Jiang, Eur. J. Med. Chem. 2018, 146, 251.

[17] A. Cleasby et. al. PLoS ONE 2014, 9(6): e98896. doi:10.1371/journal.pone.0098896.

[18] P. Canning, F. J. Sorrell, A. N. Bullock, Free Radic. Biol. Med. 2015, 88, 101.

[19] P. Canning, et. al. J. Biol. Chem. 2013, 288, 7803 
[20] K. T. Tran et. al. J. Med. Chem. 2019, 62, 8028.

[21] R. Ahmad, D. Raina, C. Meyer, S. Kharbanda, D. Kufe, J. Biol. Chem. 2006, 281, 35764

[22] M. H. L. Wong et al. J. Med. Chem. 2016, 59, 2396.

[23] For a discussion, see: K. Senkane et. al. Angew. Chem. Int. Ed. 2019, 58, 11385.

[24] a) P. Ottis et. al. ACS Chem. Biol. 2019, 14, 2215; b) L. Zhang, B. Riley-Gillis, P. Vijay, Y. Shen, Mol. Cancer. Ther. 2019, 18, 1302 . 


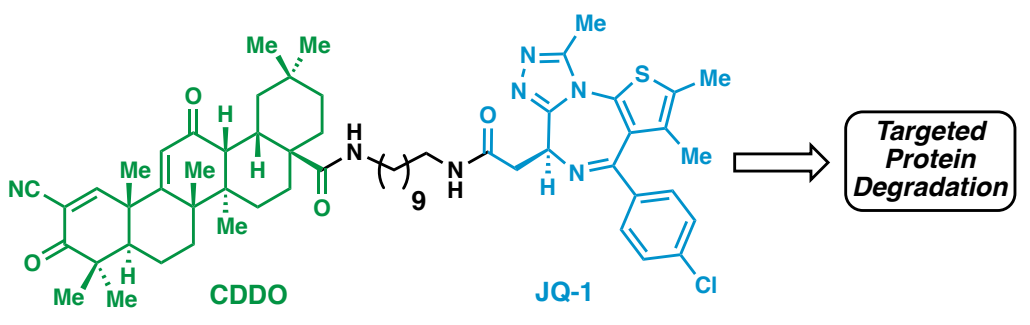

Bingqi Tong, Mai Luo, Yi Xie, Jessica Spradlin, John A. Tallarico, Jeffrey M. McKenna, Markus Schirle, Thomas J. Maimone, ${ }^{*}$ and Daniel K. Nomura*

Page No. - Page No.

Targeted Protein Degradation via a Covalent Reversible Degrader Based on CDDO 


\section{Synthetic Supporting Information}

\section{General Procedures}

Unless otherwise noted, all reactions were performed in flame-dried glassware under a positive pressure of nitrogen or argon. Air- and moisture-sensitive liquids were transferred via syringe. Dry dichloromethane and $N, N$-Dimethylformamide were obtained by passing these previously degassed solvents through activated alumina columns. Bardoxolone methyl (CDDO-Me) was purchased from Sigma-Aldrich. Oleanolic acid was purchased from Acros Organics. (+)-JQ1 was purchased from Enovation Chemicals. All the reagents were used as received from commercial sources, unless stated otherwise. Reactions were monitored by thin layer chromatography (TLC) on TLC silica gel $60 \mathrm{~F}_{254}$ glass plates (EMD Millipore) and visualized by UV irradiation and staining with $p$-anisaldehyde, phosphomolybdic acid, or Ninhydrin. Volatile solvents were removed under reduced pressure using a rotary evaporator. Flash column

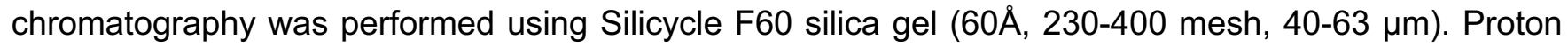
nuclear magnetic resonance $\left({ }^{1} \mathrm{H} N M R\right)$ and carbon nuclear magnetic resonance $\left({ }^{13} \mathrm{C} N \mathrm{NM}\right)$ spectra were recorded on Bruker AV-600 and AV-700 spectrometers operating at 600 and $700 \mathrm{MHz}$ for ${ }^{1} \mathrm{H} N M R$, and 151 and $176 \mathrm{MHz}$ for ${ }^{13} \mathrm{C}$ NMR. Chemical shifts are reported in parts per million (ppm) with respect to the residual solvent signal $\mathrm{CDCl}_{3}\left({ }^{1} \mathrm{H}\right.$ NMR: $\left.\delta 7.26 ;{ }^{13} \mathrm{C} N M R: \delta 77.16\right), \mathrm{CD}_{2} \mathrm{Cl}_{2}\left({ }^{1} \mathrm{H} \mathrm{NMR}: \delta 5.32 ;{ }^{13} \mathrm{C}\right.$ NMR: $\delta$ 53.84). Peak multiplicities are reported as follows: $s=$ singlet, $d=$ doublet, $t=$ triplet, $d d=$ doublet of doublets, $t t=$ triplet of triplets, $m=$ multiplet, $b r=$ broad signal. IR spectra were recorded on a Bruker Vertex80 FTIR spectrometer. High-resolution mass spectra (HRMS) were obtained by the QB3/chemistry mass spectrometry facility at the University of California, Berkeley using a Thermo LTQ-FT mass spectrometer with electrospray ionization (ESI) technique. 

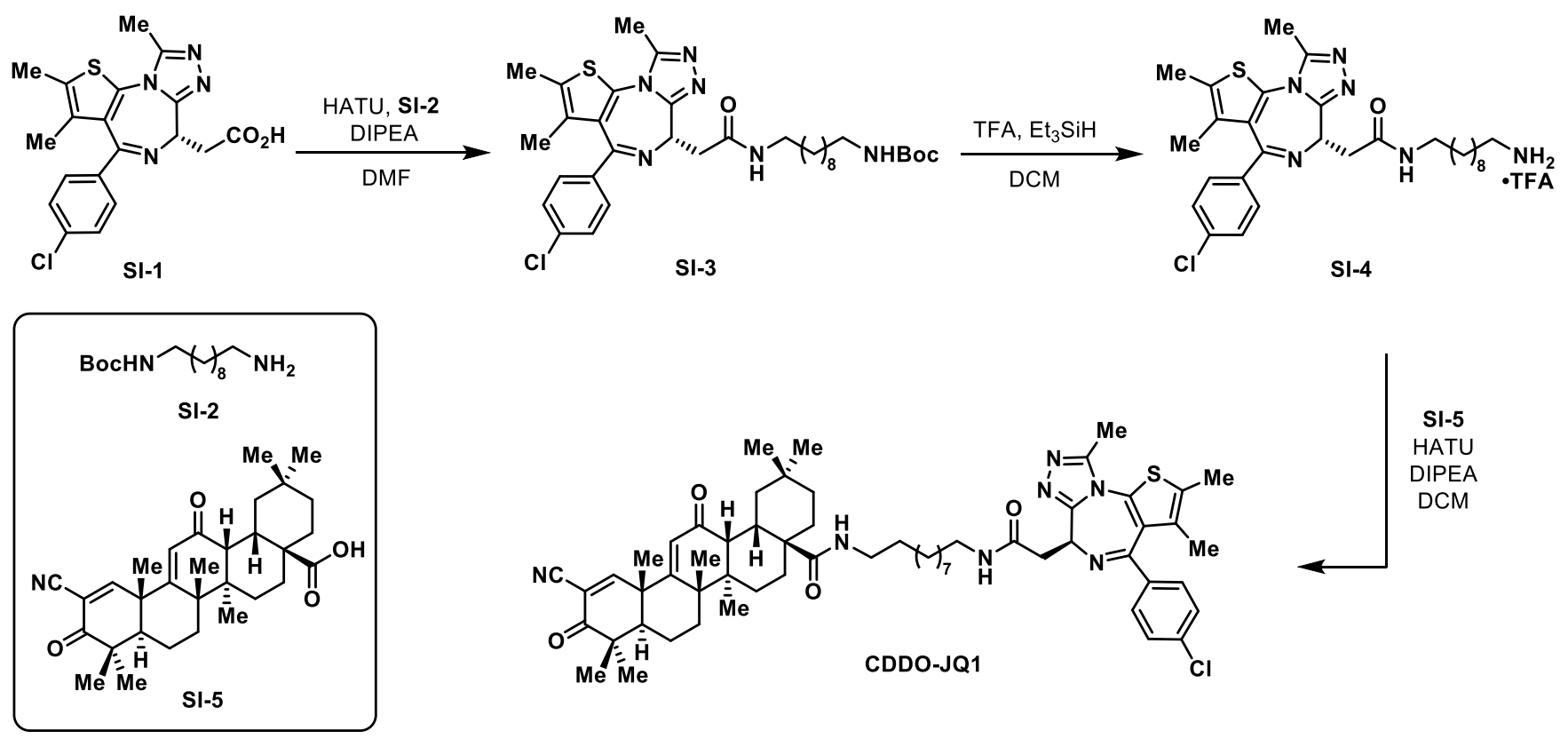

SI Scheme 1. Synthesis of degrader CDDO-JQ1

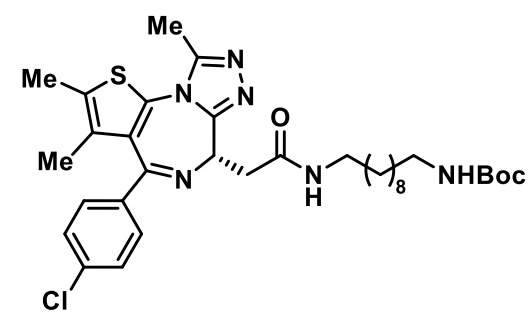

Compound SI-3: To a $10 \mathrm{~mL}$ reaction tube was added SI-1 $^{1}(21.7 \mathrm{mg}$, $0.0541 \mathrm{mmol}, 1.0$ equiv) and DMF (1.0 mL). DIPEA (37.7 $\mu \mathrm{L}, 0.216$ mmol, 4.0 equiv) and HATU (22.6 mg, $0.0595 \mathrm{mmol}, 1.1$ equiv) were added at $0{ }^{\circ} \mathrm{C}$ and the reaction mixture was stirred at room temperature for 30 minutes. The reaction mixture was then cooled back to $0{ }^{\circ} \mathrm{C}$ and amine $\mathbf{S I - 2}{ }^{2}$ (29.5 $\mathrm{mg}, 0.108 \mathrm{mmol}, 2.0$ equiv) was added. The resulting mixture was allowed to stir at room temperature for 1 hour before quenching with saturated aq. $\mathrm{NH}_{4} \mathrm{Cl}$ $(30 \mathrm{~mL})$. The layers were separated, and the aqueous phase was extracted with EtOAc $(3 \times 5 \mathrm{~mL})$. The combined organic layer was dried over $\mathrm{Na}_{2} \mathrm{SO}_{4}$ and concentrated in vacuo. The residue was purified by column chromatography ( $3 \% \mathrm{MeOH} / \mathrm{CH}_{2} \mathrm{Cl}_{2}$ ) to afford compound $\mathbf{S I - 3}(30.0 \mathrm{mg}, 84 \%$ yield) as a yellow oil: ${ }^{1} \mathrm{H} \mathrm{NMR}\left(600 \mathrm{MHz}, \mathrm{CDCl}_{3}\right) \delta 7.40(\mathrm{~d}, J=8.1 \mathrm{~Hz}, 2 \mathrm{H}), 7.32(\mathrm{~d}, J=8.2 \mathrm{~Hz}, 2 \mathrm{H}), 6.39(\mathrm{br}, 1 \mathrm{H}), 4.61(\mathrm{t}$, $J=7.0 \mathrm{~Hz}, 1 \mathrm{H}), 4.51(\mathrm{br}, 1 \mathrm{H}), 3.55(\mathrm{dd}, J=14.0,7.5 \mathrm{~Hz}, 1 \mathrm{H}), 3.39-3.27(\mathrm{~m}, 2 \mathrm{H}), 3.22(\mathrm{dt}, J=13.2,6.6$ $\mathrm{Hz}, 1 \mathrm{H}), 3.10(\mathrm{br}, 2 \mathrm{H}), 2.66(\mathrm{~s}, 3 \mathrm{H}), 2.40(\mathrm{~s}, 3 \mathrm{H}), 1.67(\mathrm{~s}, 3 \mathrm{H}), 1.56-1.42(\mathrm{~m}, 4 \mathrm{H}), 1.44(\mathrm{~s}, 9 \mathrm{H}), 1.33-$ $1.22(\mathrm{~m}, 12 \mathrm{H}) ;{ }^{13} \mathrm{C}$ NMR $\left(151 \mathrm{MHz}, \mathrm{CDCl}_{3}\right) \delta 170.5,164.0,156.1,155.8,150.0,136.9,136.8,132.3$, 131.1, 130.9, 130.6, 129.9, 128.9, 79.1, 54.7, 40.8, 39.85, 39.77, 30.2, 29.68, 29.61, 29.59, 29.41, 29.40, 28.6, 27.1, 26.9, 14.5, 13.2, 12.0; IR (thin film) vmax 3347, 2956, 2924, 2853, 1721, 1453, 1376, 1274, 1176, 1110, $714 \mathrm{~cm}^{-1}$; HRMS (ESI) calcd. for $\left[\mathrm{C}_{34} \mathrm{H}_{48} \mathrm{O}_{3} \mathrm{~N}_{6} \mathrm{CIS}\right]^{+}\left([\mathrm{M}+\mathrm{H}]^{+}\right): \mathrm{m} / \mathrm{z} 655.3192$, found: 655.3180 . 


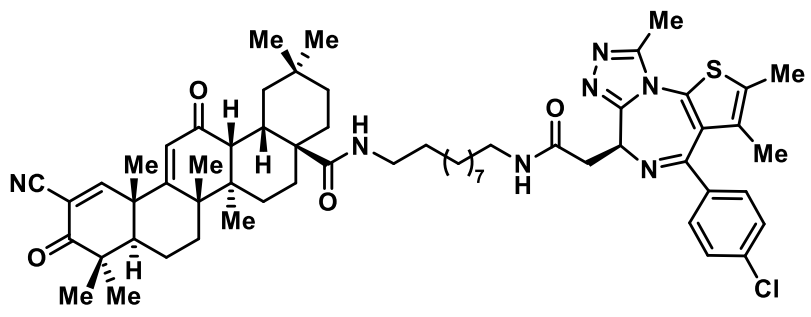

Degrader CDDO-JQ1: i. To a $10 \mathrm{~mL}$ reaction tube was added compound SI-3 $(24.3 \mathrm{mg}, 0.0371 \mathrm{mmol}, 1.0$ equiv), triethylsilane ( $12.0 \mu \mathrm{L}, 0.0742 \mathrm{mmol}, 2.0$ equiv) and $\mathrm{CH}_{2} \mathrm{Cl}_{2}(0.6 \mathrm{~mL})$. Trifluoroacetic acid $(0.2 \mathrm{~mL})$ was added slowly at $0{ }^{\circ} \mathrm{C}$. The reaction mixture was allowed to warm up to room temperature and stirred for 3 hours. After completion of the reaction, the mixture was concentrated by rotatory evaporation. The residue was dried under high vacuum for 3 hours to provide crude compound SI-4 as a yellow oil, which was used directly in the next step without further purification.

ii. To a $10 \mathrm{~mL}$ reaction tube was added CDDO $(\mathrm{SI}-5)^{3}(12.7 \mathrm{mg}, 0.0258 \mathrm{mmol}, 1.0$ equiv), HATU (10.3 $\mathrm{mg}, 0.0271 \mathrm{mmol}, 1.05$ equiv), DIPEA (13.5 $\mu \mathrm{L}, 0.0775 \mathrm{mmol}, 3.0$ equiv) and $\mathrm{CH}_{2} \mathrm{Cl}_{2}(0.4 \mathrm{~mL})$. After stirring at room temperature for 12 hours, the reaction was quenched with saturated aq. $\mathrm{NH}_{4} \mathrm{Cl}$ and extracted with $\mathrm{CH}_{2} \mathrm{Cl}_{2}(3 \times 1 \mathrm{~mL})$. The combined organic layer was dried over $\mathrm{Na}_{2} \mathrm{SO}_{4}$ and concentrated in vacuo. The resulting activated ester was then transferred into another reaction tube containing the previously prepared crude compound SI-4 (0.0371 mmol, 1.4 equiv). $\mathrm{CH}_{2} \mathrm{Cl}_{2}(0.4 \mathrm{~mL})$ and DIPEA (22.5 $\mu \mathrm{L}, 0.129 \mathrm{mmol}, 5.0$ equiv) was added and the reaction mixture was stirred at room temperature for 12 hours before quenching with saturated aq. $\mathrm{NH}_{4} \mathrm{Cl}$. The layers were separated, and the aqueous phase was extracted with $\mathrm{CH}_{2} \mathrm{Cl}_{2}(3 \times 1 \mathrm{~mL})$. The combined organic layer was dried over $\mathrm{Na}_{2} \mathrm{SO}_{4}$ and concentrated in vacuo. The residue was purified by column chromatography $\left(4 \% \mathrm{MeOH} / \mathrm{CH}_{2} \mathrm{Cl}_{2}\right)$ followed by preparative TLC (5\% MeOH/CHCl 3 ) to afford degrader CDDO-JQ1 (12.8 mg, 48\% yield) as a colorless oil which slowly solidifies: ${ }^{1} \mathrm{H}$ NMR $\left(700 \mathrm{MHz}, \mathrm{CD}_{2} \mathrm{Cl}_{2}\right) \delta 8.09(\mathrm{~s}, 1 \mathrm{H}), 7.43(\mathrm{~d}, J=8.3 \mathrm{~Hz}, 2 \mathrm{H}), 7.34(\mathrm{~d}, J$ $=8.3 \mathrm{~Hz}, 2 \mathrm{H}), 6.49(\mathrm{t}, J=5.9 \mathrm{~Hz}, 1 \mathrm{H}), 5.95(\mathrm{~s}, 1 \mathrm{H}), 5.85(\mathrm{t}, J=5.8 \mathrm{~Hz}, 1 \mathrm{H}), 4.57(\mathrm{t}, J=6.9 \mathrm{~Hz}, 1 \mathrm{H}), 3.42$ (dd, $J=14.3,7.2 \mathrm{~Hz}, 1 \mathrm{H}), 3.32-3.15(\mathrm{~m}, 5 \mathrm{H}), 3.08(\mathrm{~d}, J=4.6 \mathrm{~Hz}, 1 \mathrm{H}), 2.89-2.84(\mathrm{~m}, 1 \mathrm{H}), 2.63(\mathrm{~s}, 3 \mathrm{H})$, $2.40(\mathrm{~s}, 3 \mathrm{H}), 2.00(\mathrm{td}, J=14.0,3.9 \mathrm{~Hz}, 1 \mathrm{H}), 1.81-1.69(\mathrm{~m}, 5 \mathrm{H}), 1.67(\mathrm{~s}, 3 \mathrm{H}), 1.57-1.47(\mathrm{~m}, 6 \mathrm{H}), 1.46$ $(\mathrm{s}, 3 \mathrm{H}), 1.45-1.39(\mathrm{~m}, 1 \mathrm{H}), 1.36-1.19(\mathrm{~m}, 16 \mathrm{H}), 1.32(\mathrm{~s}, 3 \mathrm{H}), 1.23(\mathrm{~s}, 3 \mathrm{H}), 1.21-1.15(\mathrm{~m}, 1 \mathrm{H}), 1.14$ (s, 3H), 1.00 (s, 3H), 0.96 (s, 3H), 0.89 (s, 3H); $\left.{ }^{13} \mathrm{C} \mathrm{NMR} \mathrm{(151} \mathrm{MHz,} \mathrm{CD}_{2} \mathrm{Cl}_{2}\right) \delta$ 199.4, 197.4, 177.0, 170.4, 168.9, 166.6, 164.2, 156.2, 150.4, 137.3, 136.9, 132.8, 131.4, 131.2, 130.7, 130.4, 129.0, 124.4, 115.1, $114.7,54.9,49.8,48.0,46.7,46.3,45.4,43.0,42.5,39.97,39.89,39.78,36.4,35.0,34.5,33.4,32.19$, $32.07,30.9,30.2,30.1,30.0,29.83,29.81,29.65,29.65,28.2,27.4,27.3,27.0,26.7,25.0,23.6,23.3$, 21.8, 18.6, 14.6, 13.2, 12.0; IR (thin film) vmax 3346, 2924, 2852, 1715, 1661, 1593, 1562, 1532, 1465, 1383, 1262, 1091, 1015, $805 \mathrm{~cm}^{-1}$; HRMS (ESI) calcd for $\left[\mathrm{C}_{60} \mathrm{H}_{79} \mathrm{O}_{4} \mathrm{~N}_{7} \mathrm{ClS}\right]^{+}\left([\mathrm{M}+\mathrm{H}]^{+}\right): \mathrm{m} / \mathrm{z} 1028.5597$, found: 1028.5599 . 

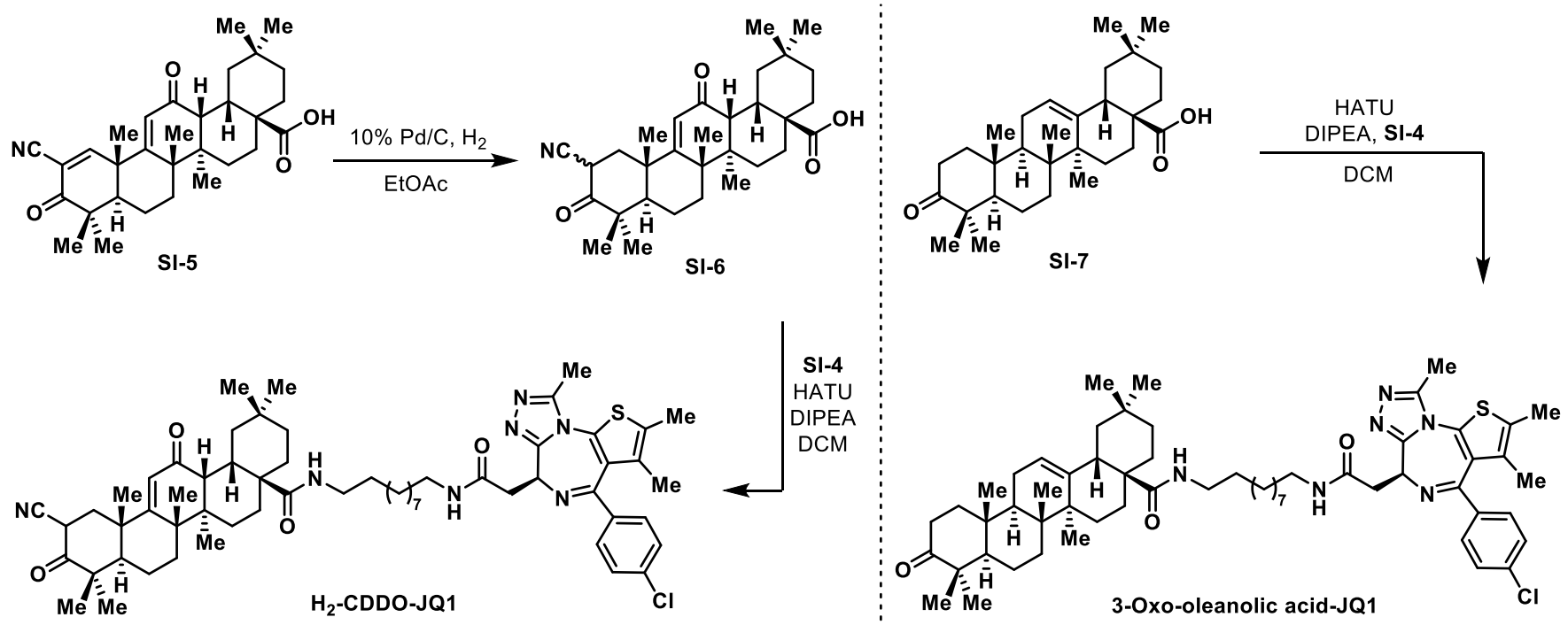

SI Scheme 2. Synthesis of negative control compounds $\mathrm{H}_{2}$-CDDO-JQ1 and 3-Oxo-oleanolic acid-JQ1.

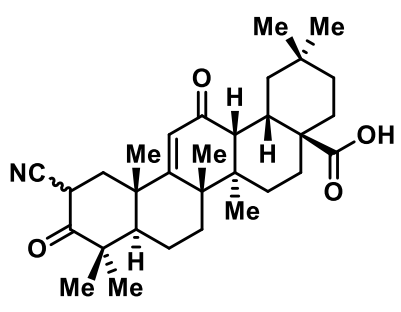

Compound SI-6: To a solution of CDDO (SI-5) $(5.8 \mathrm{mg}, 0.012 \mathrm{mmol}, 1.0$ equiv) in EtOAc $(1 \mathrm{~mL})$ was added $10 \% \mathrm{Pd} / \mathrm{C}(5 \mathrm{mg})$ in one portion. Hydrogen gas was bubbled through the reaction mixture via a long steel needle that attached to a hydrogen balloon. After 5 minutes, the needle was lifted above the solvent level and the reaction was stirred for additional 20 minutes under $\mathrm{H}_{2}$ atmosphere. The reaction mixture was filtered through celite, washed with EtOAc ( $2 \mathrm{~mL}$ ) and concentrated in vacuo to afford compound SI-6 (5.6 mg, 96\% yield) as a white solid, which was pure enough ( $>95 \%$ by ${ }^{1} \mathrm{H}$ NMR) to be used in the next step without further purification. The product exists as a mixture of enol- and keto- forms and diastereomers (all peaks are listed): ${ }^{1} \mathrm{H}$ NMR $\left(600 \mathrm{MHz}, \mathrm{CDCl}_{3}\right) \delta 5.77(\mathrm{~s}, 0.65 \mathrm{H}), 5.74(\mathrm{~s}, 0.21 \mathrm{H}), 5.72(\mathrm{~s}, 0.14 \mathrm{H}), 3.98(\mathrm{dd}, J=13.8,5.4 \mathrm{~Hz}, 0.21 \mathrm{H})$, $3.93(\mathrm{dd}, J=11.7,8.1 \mathrm{~Hz}, 0.14 \mathrm{H}), 3.06-2.98(\mathrm{~m}, 1 \mathrm{H}), 2.98-2.90(\mathrm{~m}, 1 \mathrm{H}), 2.71-2.59(\mathrm{~m}, 0.35 \mathrm{H}), 2.42$ (d, $J=15.0 \mathrm{~Hz}, 0.65 \mathrm{H}$ ), 2.37 (dd, $J=13.5,8.1 \mathrm{~Hz}, 0.14 \mathrm{H}$ ), 2.25 (d, $J=15.0 \mathrm{~Hz}, 0.65 \mathrm{H}$ ), 2.03 (t, $J=13.5$ $\mathrm{Hz}, 0.21 \mathrm{H}), 1.98-1.16(\mathrm{~m}, 24 \mathrm{H}), 1.15(\mathrm{~s}, 0.42 \mathrm{H}), 1.14(\mathrm{~s}, 0.63 \mathrm{H}), 1.12(\mathrm{~s}, 1.95 \mathrm{H}), 1.05(\mathrm{~s}, 0.42 \mathrm{H}), 1.00$ (s, 4.95H), 0.99 (s, 0.63H), $0.90(\mathrm{~s}, 3 \mathrm{H}) ;{ }^{13} \mathrm{C} \mathrm{NMR}\left(151 \mathrm{MHz}, \mathrm{CDCl}_{3}\right) \delta 206.3,204.1,199.7,199.5,199.1$, 183.2, 182.9, 175.3, 175.1, 173.7, 171.5, 126.4, 124.6, 123.7, 118.7, 117.1, 116.6, 79.2, 51.8, 49.8, 49.72, 49.70, 49.4, 48.6, 48.5, 47.2, 47.13, 47.11, 47.06, 45.7, 45.6, 45.4, 42.9, 42.3, 42.04, 42.00, 41.9, 39.6, 38.9, 38.73, 38.69, 38.2, 37.5, 36.0, 35.9, 35.8, 35.7, 34.6, 34.5, 33.4, 33.1, 33.0, 32.5, 31.59, 31.58, $31.3,30.80,30.77,30.5,29.8,28.9,28.3,28.2,28.1,28.0,26.9,25.1,24.3,24.1,23.22,23.18,23.16$, 23.12, 22.8, 22.7, 22.6, 21.8, 21.71, 21.68, 21.57, 20.01, 19.96, 19.3, 18.94, 18.88; IR (thin film) 2927, 2856, 1722, 1694, 1662, 1466, 1385, 1261, 1241, 1186, 1161, 883, 807, $750 \mathrm{~cm}^{-1}$; HRMS (ESI) calcd for $\left[\mathrm{C}_{31} \mathrm{H}_{42} \mathrm{O}_{4} \mathrm{~N}\right]^{-}\left([\mathrm{M}-\mathrm{H}]^{-}\right): \mathrm{m} / \mathrm{z} 492.3119$, found: 492.3120 . 


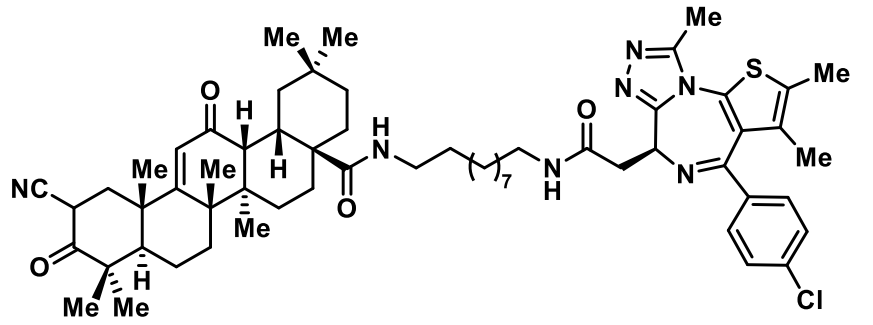

$\mathbf{H}_{2}$-CDDO-JQ1: To a $10 \mathrm{~mL}$ reaction tube was added compound SI-6 $(5.6 \mathrm{mg}, 0.011 \mathrm{mmol}, 1.0$ equiv), HATU (4.7 mg, $0.012 \mathrm{mmol}, 1.1$ equiv), DIPEA (5.9 $\mu \mathrm{L}, 0.034 \mathrm{mmol}, 3.0$ equiv) and $\mathrm{CH}_{2} \mathrm{Cl}_{2}$ $(0.4 \mathrm{~mL})$. After stirring at room temperature for 12 hours, the reaction was quenched with saturated aq. $\mathrm{NH}_{4} \mathrm{Cl}$ and extracted with $\mathrm{CH}_{2} \mathrm{Cl}_{2}(3 \times 1 \mathrm{~mL})$. The combined organic layer was dried over $\mathrm{Na}_{2} \mathrm{SO}_{4}$ and concentrated in vacuo. The resulting activated ester was then transferred into another reaction tube containing the previously prepared crude compound SI-4 (0.017 mmol, 1.5 equiv). $\mathrm{CH}_{2} \mathrm{Cl}_{2}(0.4 \mathrm{~mL})$ and DIPEA (9.8 $\mu \mathrm{L}, 0.056 \mathrm{mmol}, 5.0$ equiv) was added and the reaction mixture was stirred at room temperature for 12 hours before quenching with saturated aq. $\mathrm{NH}_{4} \mathrm{Cl}$. The layers were separated, and the aqueous phase was extracted with $\mathrm{CH}_{2} \mathrm{Cl}_{2}(3 \times 1 \mathrm{~mL})$. The combined organic layer was dried over $\mathrm{Na}_{2} \mathrm{SO}_{4}$ and concentrated in vacuo. The residue was purified by preparative TLC $\left(5 \% \mathrm{MeOH} / \mathrm{CHCl}_{3}\right)$ to afford $\mathbf{H}_{2}$-CDDO-JQ1 (5.2 mg, 45\% yield) as a colorless oil which slowly solidifies (mixture of diasteromers and enol/keto tautomers): ${ }^{1} \mathrm{H}$ NMR $\left(600 \mathrm{MHz}, \mathrm{CD}_{2} \mathrm{Cl}_{2}\right) \delta 7.43(\mathrm{~d}, \mathrm{~J}=8.4 \mathrm{~Hz}, 2 \mathrm{H}), 7.35$ (d, $J=8.3 \mathrm{~Hz}, 2 \mathrm{H}), 6.47(\mathrm{t}, J=5.8 \mathrm{~Hz}, 0.6 \mathrm{H}), 6.47(\mathrm{t}, J=5.8 \mathrm{~Hz}, 0.4 \mathrm{H}), 5.91-5.80(\mathrm{~m}, 1 \mathrm{H})$, ), $5.74(\mathrm{~s}, 0.4 \mathrm{H})$, $5.72(\mathrm{~s}, 0.4 \mathrm{H}), 5.69(\mathrm{~s}, 0.2 \mathrm{H}), 4.62-4.54(\mathrm{~m}, 1 \mathrm{H}), 4.04(\mathrm{dd}, J=14.1,5.1 \mathrm{~Hz}, 0.4 \mathrm{H}), 3.96(\mathrm{dd}, J=12.0$, $7.8 \mathrm{~Hz}, 0.2 \mathrm{H}), 3.49-3.39(\mathrm{~m}, 1 \mathrm{H}), 3.34-3.14(\mathrm{~m}, 5 \mathrm{H}), 3.07-2.99(\mathrm{~m}, 1 \mathrm{H}), 2.89-2.81(\mathrm{~m}, 1 \mathrm{H}), 2.70-$ $1.18(\mathrm{~m}, 48 \mathrm{H}), 1.18-1.14(\mathrm{~m}, 3 \mathrm{H}), 1.13-1.10(\mathrm{~m}, 3 \mathrm{H}), 1.05-0.95(\mathrm{~m}, 6 \mathrm{H}), 0.92-0.87(\mathrm{~m}, 3 \mathrm{H}) ;{ }^{13} \mathrm{C}$ $\operatorname{NMR}\left(151 \mathrm{MHz}, \mathrm{CD}_{2} \mathrm{Cl}_{2}\right) \delta 207.3,205.0,200.0,199.6,177.10,177.06,175.9,175.5,174.2,171.4,170.43$, $170.35,164.24,164.18,156.15,156.10,150.5,150.4,137.29,137.26,136.92,136.89,132.8,132.7$, $131.5,131.4,131.17,131.15,130.8,130.7,130.4,129.0,126.6,124.6,123.7,119.1,117.7,117.3,80.1$, 54.92, 54.90, 52.0, 49.8, 49.66, 49.64, 49.4, 48.8, 47.3, 46.8, 46.75, 46.73, 46.1, 46.0, 45.8, 43.3, 42.7, $42.25,42.23,42.1,39.95,39.89,39.88,39.8,39.10,39.05,38.99,38.8,38.0,36.6,36.5,36.4,36.1$, $35.02,34.99,34.6,33.45,33.43,32.8,32.3,32.2,31.6,30.95,30.92,30.8,30.30,30.26,30.15,30.10$, $30.05,30.02,29.99,29.91,29.83,29.80,29.73,29.67,29.64,28.9,28.3,28.24,28.16,27.9,27.6,27.43$, 27.40, 27.3, 27.0, 24.9, 24.6, 24.3, 23.65, 23.54, 23.51, 23.48, 23.33, 23.29, 23.2, 21.9, 21.80, 21.75, $21.68,20.0,19.9,19.6,19.22,19.15,14.6,13.2,12.0$; IR (thin film) vmax 3345, 2924, 2853, 1728, 1660, $1595,1532,1465,1417,1382,1091,1015,840,805,721 \mathrm{~cm}^{-1} ; \mathrm{HRMS}(\mathrm{ESI})$ calcd for $\left[\mathrm{C}_{60} \mathrm{H}_{81} \mathrm{O}_{4} \mathrm{~N}_{7} \mathrm{CIS}^{+}\right.$ $\left([\mathrm{M}+\mathrm{H}]^{+}\right): m / z$ 1030.5754, found: 1030.5744 . 


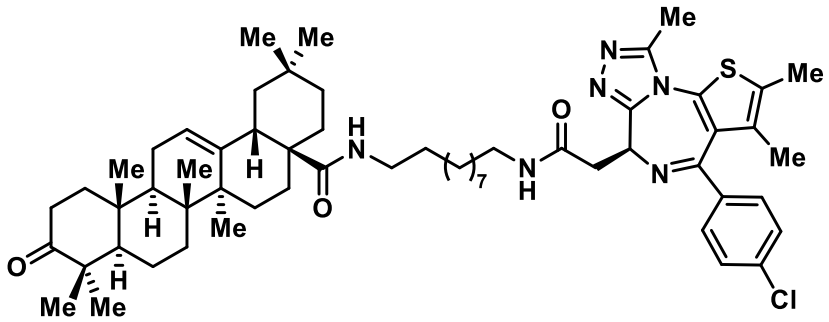

3-Oxo-oleanolic acid-JQ1: To a $10 \mathrm{~mL}$ reaction tube was added compound SI-7 ${ }^{4}(9.3 \mathrm{mg}, 0.0204 \mathrm{mmol}$, 1.0 equiv) and $\mathrm{CH}_{2} \mathrm{Cl}_{2}(1.0 \mathrm{~mL})$. The resulting solution was cooled to $0{ }^{\circ} \mathrm{C}$, and DIPEA $(14.3 \mu \mathrm{L}, 0.0818$ mmol, 4.0 equiv) and HATU ( $8.5 \mathrm{mg}, 0.0225 \mathrm{mmol}$, 1.1 equiv) were added. The reaction mixture was allowed to stir at room temperature for 30 min before quenching with saturated aq. $\mathrm{NH}_{4} \mathrm{Cl}$. The layers were separated, and the aqueous phase was extracted with $\mathrm{CH}_{2} \mathrm{Cl}_{2}(3 \times 1 \mathrm{~mL})$. The combined organic layer was dried over $\mathrm{Na}_{2} \mathrm{SO}_{4}$ and concentrated in vacuo. The resulting activated ester was then transferred into another reaction tube containing previously prepared crude compound SI-4 (17.0 mg, $0.0307 \mathrm{mmol}, 1.5$ equiv), DIPEA (35.5 $\mu \mathrm{L}, 0.204 \mathrm{mmol}, 10.0$ equiv) and $\mathrm{CH}_{2} \mathrm{Cl}_{2}(1.0 \mathrm{~mL})$. The reaction mixture was allowed to stir at room temperature for 12 hours before quenching with saturated aq. $\mathrm{NH}_{4} \mathrm{Cl}$. The layers were separated, and the aqueous phase was extracted with $\mathrm{CH}_{2} \mathrm{Cl}_{2}(3 \times 1 \mathrm{~mL})$. The combined organic layer was dried over $\mathrm{Na}_{2} \mathrm{SO}_{4}$ and concentrated in vacuo. The residue was purified by preparative TLC (6\% MeOH/ $\mathrm{CH}_{2} \mathrm{Cl}_{2}$, developed twice) to afford 3-oxo-oleanolic acid-JQ1 (9.3 mg, 46\% yield) as a white solid: ${ }^{1} \mathrm{H}$ NMR $\left(600 \mathrm{MHz}, \mathrm{CDCl}_{3}\right) \delta 7.42-7.38(\mathrm{~m}, 2 \mathrm{H}), 7.35-7.31(\mathrm{~m}, 2 \mathrm{H}), 6.36(\mathrm{t}, J=5.7 \mathrm{~Hz}$, $1 \mathrm{H}$ ), 5.88 (t, $J=5.5 \mathrm{~Hz}, 1 \mathrm{H}), 5.39(\mathrm{t}, J=3.6 \mathrm{~Hz}, 1 \mathrm{H}), 4.60$ (dd, $J=7.6,6.3 \mathrm{~Hz}, 1 \mathrm{H}), 3.55$ (dd, $J=14.1$, $7.7 \mathrm{~Hz}, 1 \mathrm{H}), 3.39-3.28(\mathrm{~m}, 3 \mathrm{H}), 3.21(\mathrm{dq}, J=13.2,7.0 \mathrm{~Hz}, 1 \mathrm{H}), 3.06-2.97(\mathrm{~m}, 1 \mathrm{H}), 2.67(\mathrm{~s}, 3 \mathrm{H}), 2.59$ $-2.50(\mathrm{~m}, 2 \mathrm{H}), 2.40(\mathrm{~d}, J=0.8 \mathrm{~Hz}, 3 \mathrm{H}), 2.37$ (ddd, $J=15.9,6.8,3.6 \mathrm{~Hz}, 1 \mathrm{H}), 2.03-1.92(\mathrm{~m}, 3 \mathrm{H}), 1.89$ (ddd, $J=13.2,7.3,3.7 \mathrm{~Hz}, 1 \mathrm{H}), 1.77(\mathrm{t}, J=13.3 \mathrm{~Hz}, 1 \mathrm{H}), 1.74-1.64(\mathrm{~m}, 3 \mathrm{H}), 1.67(\mathrm{~s}, 3 \mathrm{H}), 1.61-1.38$ $(\mathrm{m}, 12 \mathrm{H}), 1.36-1.18(\mathrm{~m}, 16 \mathrm{H}), 1.17(\mathrm{~s}, 3 \mathrm{H}), 1.09(\mathrm{~s}, 3 \mathrm{H}), 1.06(\mathrm{~s}, 3 \mathrm{H}), 1.05(\mathrm{~s}, 3 \mathrm{H}), 0.91(\mathrm{~s}, 3 \mathrm{H}), 0.91$ (s, 3H), 0.83 (s, 3H); ${ }^{13} \mathrm{C}$ NMR $\left(151 \mathrm{MHz}, \mathrm{CDCl}_{3}\right) \delta 217.7,178.1,170.5,164.0,155.8,150.0,145.4,137.0$, 136.8, 132.3, 131.1, 131.0, 130.6, 130.0, 128.9, 122.5, 55.4, 54.7, 47.6, 47.0, 46.9, 46.4, 42.6, 42.4, $39.86,39.82,39.6,39.5,39.3,36.9,34.32,34.30,33.2,32.7,32.1,30.9,29.70,29.70,29.64,29.52$, 29.46, 29.43, 27.5, 27.3, 27.1, 26.6, 25.8, 23.9, 23.8, 23.7, 21.6, 19.7, 17.0, 15.2, 14.5, 13.2, 12.0. IR (thin film) vmax 3346, 2925, 2854, 1705, 1654, 1593, 1532, 1457, 1419, 1381, 1274, 1176, 1110, 1091, 1014, 839, 805, 749, $714 \mathrm{~cm}^{-1}$; HRMS (ESI) calcd for $\left[\mathrm{C}_{59} \mathrm{H}_{84} \mathrm{O}_{3} \mathrm{~N}_{6} \mathrm{ClS}\right]^{+}\left([\mathrm{M}+\mathrm{H}]^{+}\right): \mathrm{m} / \mathrm{z} 991.6009$, found: 991.6005.

\section{References:}

1) Tyler, D. S.; Vappiani, J.; Cañeque, T.; Lam, E. Y. N.; Ward, A.; Gilan, O.; Chan, Y-C.; Hienzsch, A.; Rutkowska, A.; Thilo Werner, T. et al., Science 2017, 356, 1397-1401

2) Cinelli, M. A.; Cordero, B.; Dexheimer, T. S.; Pommier, Y.; Cushman, M. Bioorg. Med. Chem. 2009, 17, 7145-7155

3) Wong, M. H. L.; Bryan, H. K.; Copple, I. M.; Jenkins,R. E.; Chiu, P. H.; Bibby, J.; Berry, N. G.; Kitteringham, N. R.; Goldring,C. E.; O’Neill, P. M.; Park, B. K. J. Med. Chem. 2016, 59, 2396-2409

4) a. Eldridge, G. R.; Buckle, R. N.; Ellis, M.; Huang, Z.; Reilly, J. E. (Sequoia Sciences, Inc.), EP2712863, 2014, A1; b. Bhandari, P.; Patel, N. K.; Gangwal, R. P.; Sangamwar, A. T.; Bhutani, K. K. Bioorg. Med. Chem. Lett. 2014, 24, 4114-4119 


\section{Biological Methods Supporting Information \\ Materials}

Primary antibodies to BRD4 (Abcam, Ab128874), GAPDH (Proteintech Group Inc., 60004-1-lg), and KEAP1 (Cell Signaling Technologies, D6B12) were obtained from commercial sources and dilutions were prepared according to manufacturer recommendations. Anti-rabbit and anti-mouse seconadary antibodies were purchased from Licor (IRDye 800CW Goat anti-Rabbit IgG Secondary Antibody and IRDye 700CW Goat anti-Mouse IgG Secondary Antibody). The commercially available inhibitor compounds bortezomib (Alfa Aesar J60378MA), MLN7243 (SelleckChem S8341) and MLN4924 (SelleckChem S7109) were purchased as solids and DMSO solutions were prepared and the appropriate concentrations.

\section{Cell Culture}

231MFP cells were obtained from the were obtained from B. Cravatt and were generated from explanted tumor xenografts of MDA-MB-231 cells as previously described. They were cultured in L15 medium containing $10 \%(\mathrm{v} / \mathrm{v})$ fetal bovine serum (FBS), maintained at $37^{\circ} \mathrm{C}$ with $0 \% \mathrm{CO}_{2}$.

\section{Cell-Based Degrader Assays.}

For assaying degrader activity, cells were seeded (500 000 for 231MFP cells) into a $6 \mathrm{~cm}$ tissue culture dish (Corning) in 2.0-2.5 mL of media and allowed to adhere overnight. The following morning, media was replaced with complete media containing the desired concentration of CDDO-JQ1 diluted from a $1,000 \mathrm{X}$ stock in DMSO. For rescue study, the cells will be pre-treated with proteasome inhibitor (bortezomib, $1 \mu \mathrm{M}$ ), E1 inhibitor (MLN7243, $1 \mu \mathrm{M}$ ) or NEDDylation inhibitor (MLN4924, $1 \mu \mathrm{M}$ ) for 30 mins. After 12 hour treatment, the cell will harvest for next analyze.

\section{Western Blotting}

231MFP cells were seeded in 6 well plates to achieve $90 \%$ cell density at time of treatment, allowing cells to adhere overnight before being treated with compounds dissolved as 1,000X stocks in DMSO. After 12 hour treatment, media was aspirated and cells were washed with $500 \mu \mathrm{L}$ PBS. To harvest cells $100 \mu \mathrm{L}$ Radioimmunoprecipitation assay buffer (RIPA buffer) was added to each well and incubated 5 minutes on ice before scraping and transferring to Eppendorf tubes. The collected cells were vortexed vigorously in the lysis buffer and allowed to sit on ice 5 additional minutes before cellular debris was pelleted by spinning at maximum speed for 10 minutes at $4{ }^{\circ} \mathrm{C}$. Supernatant was transferred to new tubes and total protein was normalized by Pierce BCA Protein Assay. Samples were denatured by addition of $4 \mathrm{X}$ Laemmli's Loading dye and $30 \mu \mathrm{g}$ of protein was loaded onto $4-20 \%$ TGX Precast gels (BioRad). After gel electrophoresis proteins were transferred to a nitrocellulose membrane using semidry transfer on a Trans-Blot Turbo (BioRad) over $7 \mathrm{~min}$. The membrane was then incubated for 1 hour in $5 \%$ bovine serum albumin (BSA) in tris-buffered saline containing Tween 20 (TBST) before being incubated with the correct primary antibody overnight at $4{ }^{\circ} \mathrm{C}$. The membranes were washed in TBST before a 1 hour room temperature incubation with secondary antibodies. After a final set of washes 
blots were imaged on a LiCor CLX imager and band intensitities were quantified using Image J software. 


\begin{tabular}{|c|c|c|}
\hline 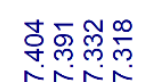 & $\underset{\substack{\infty \\
0 \\
0}}{0.0}$ & 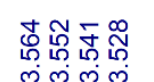 \\
\hline
\end{tabular}
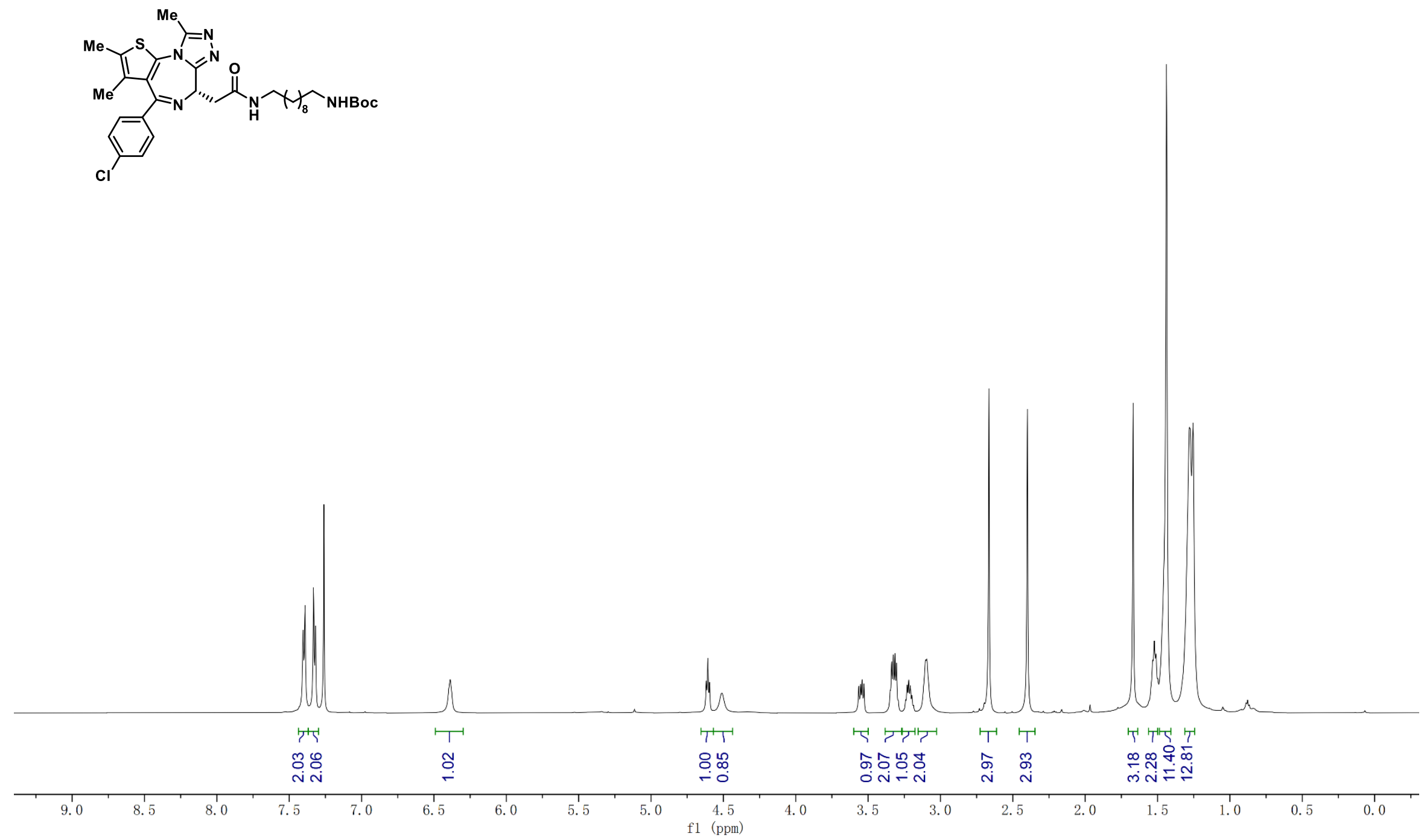

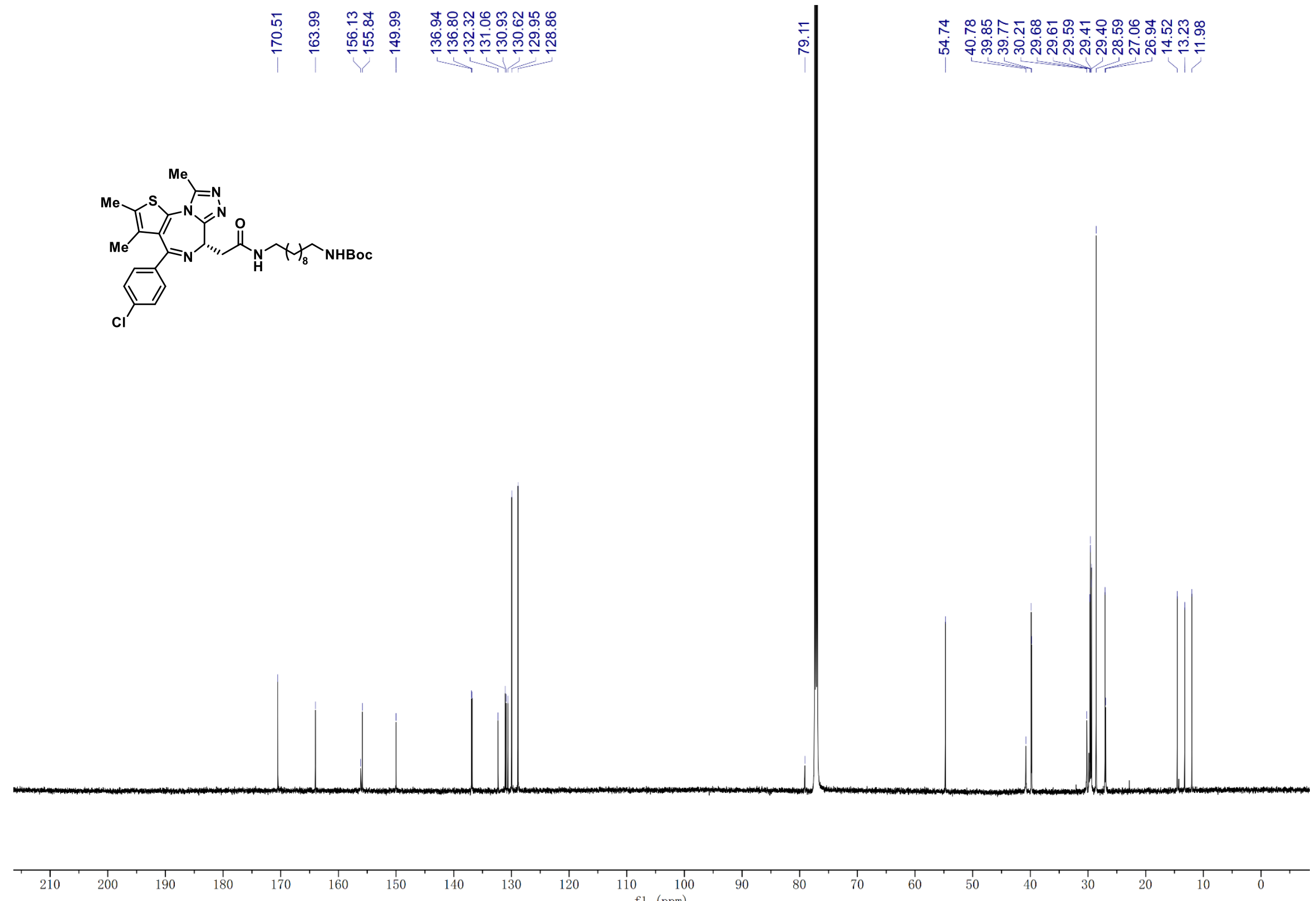


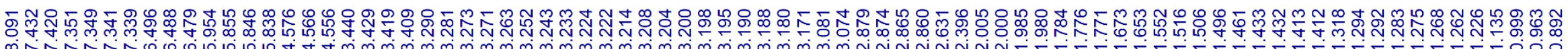
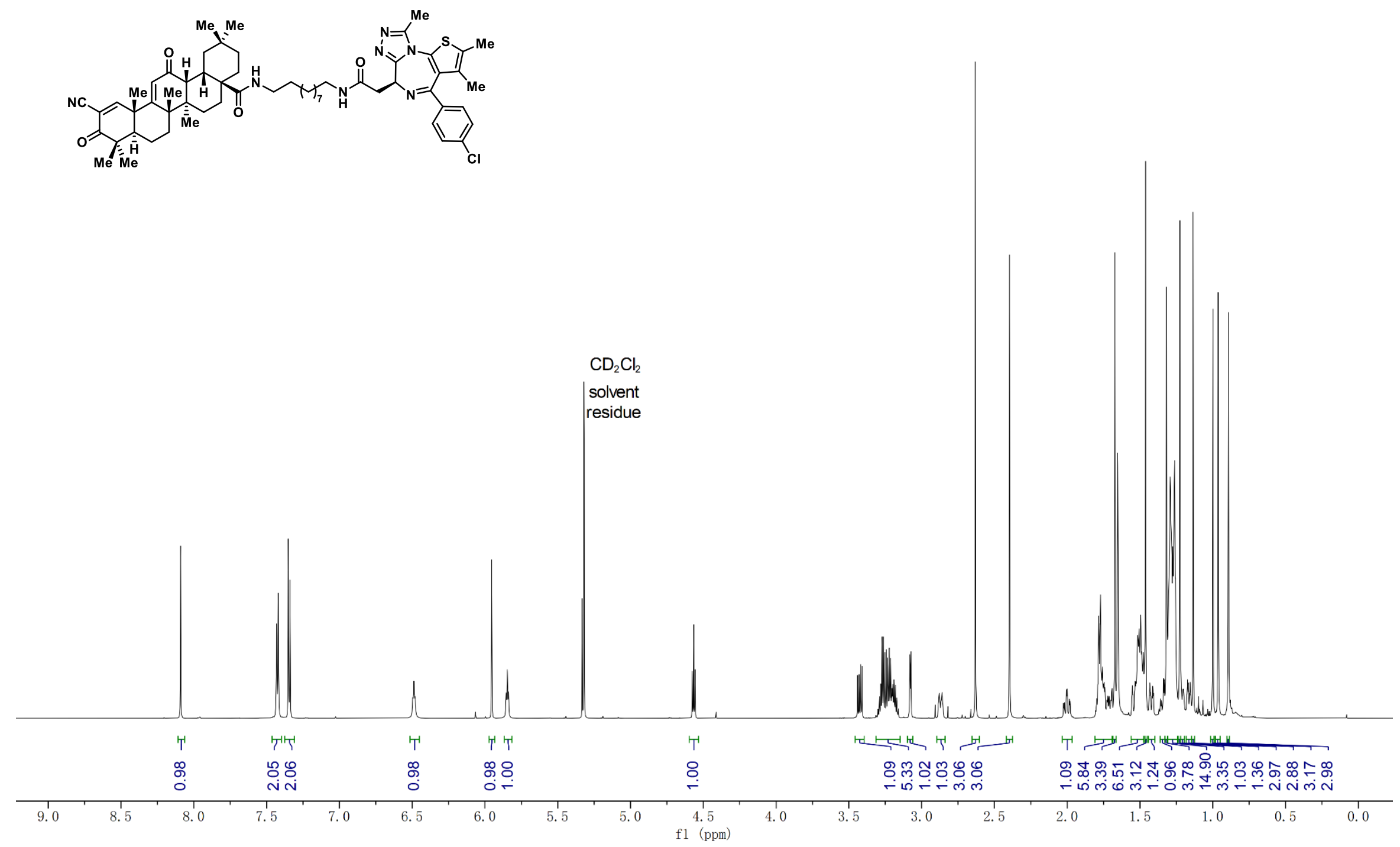

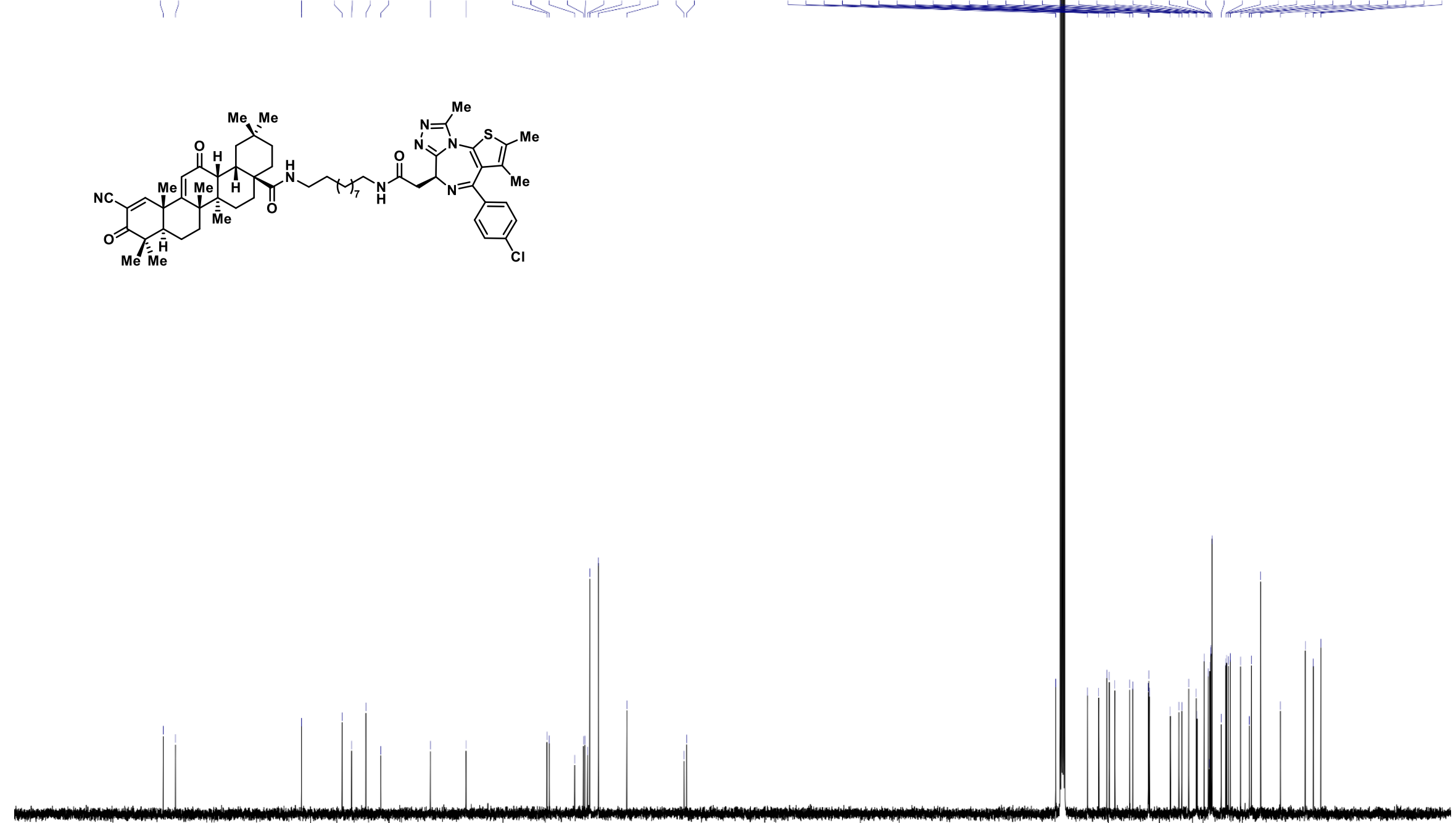


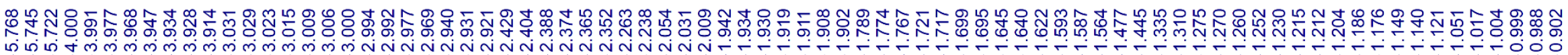
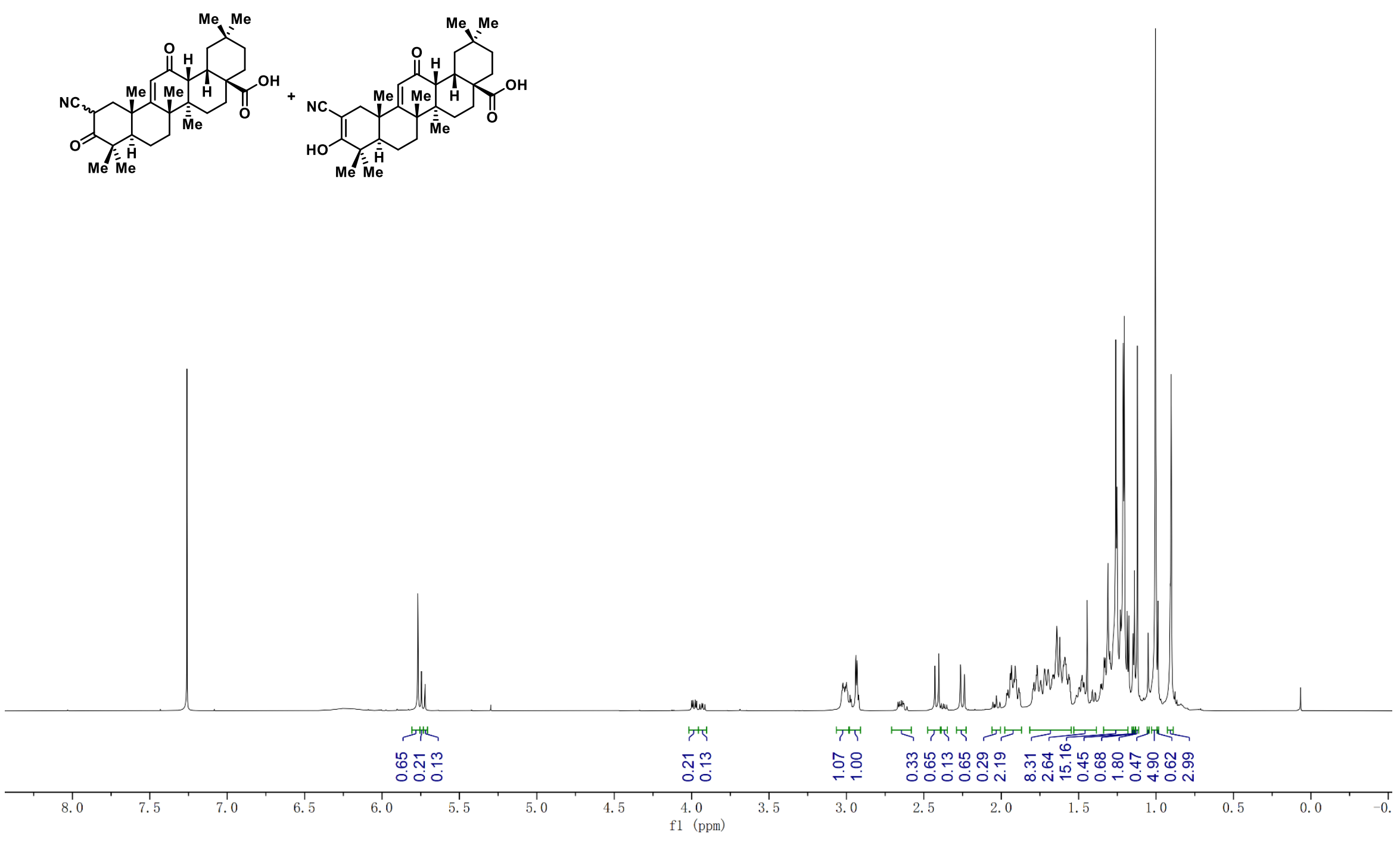


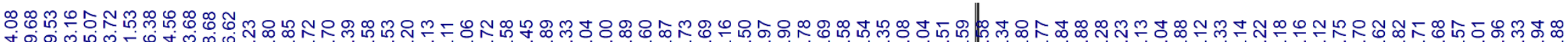

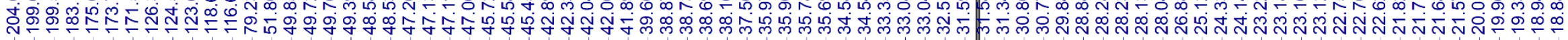
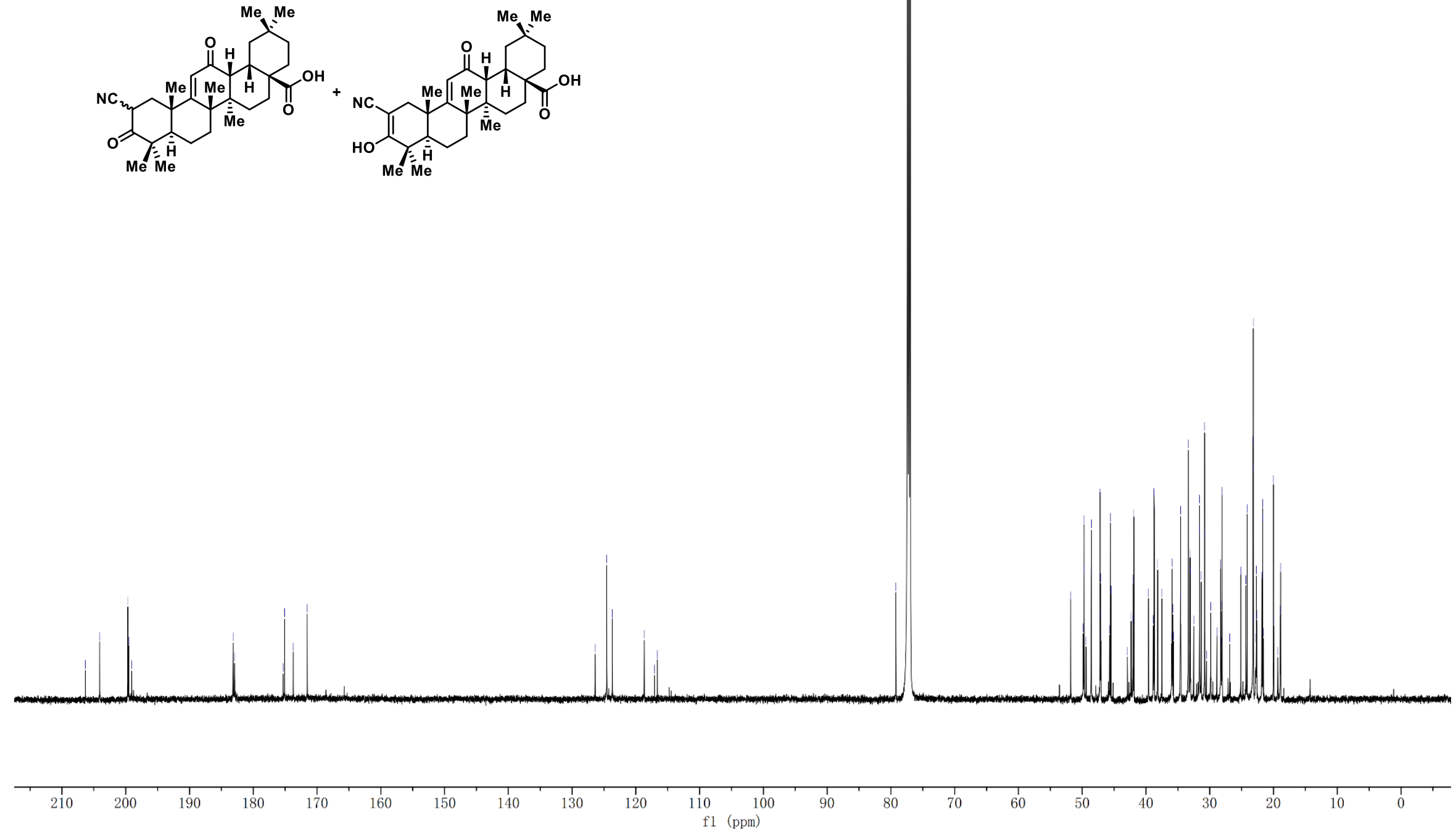


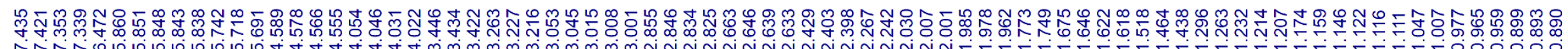
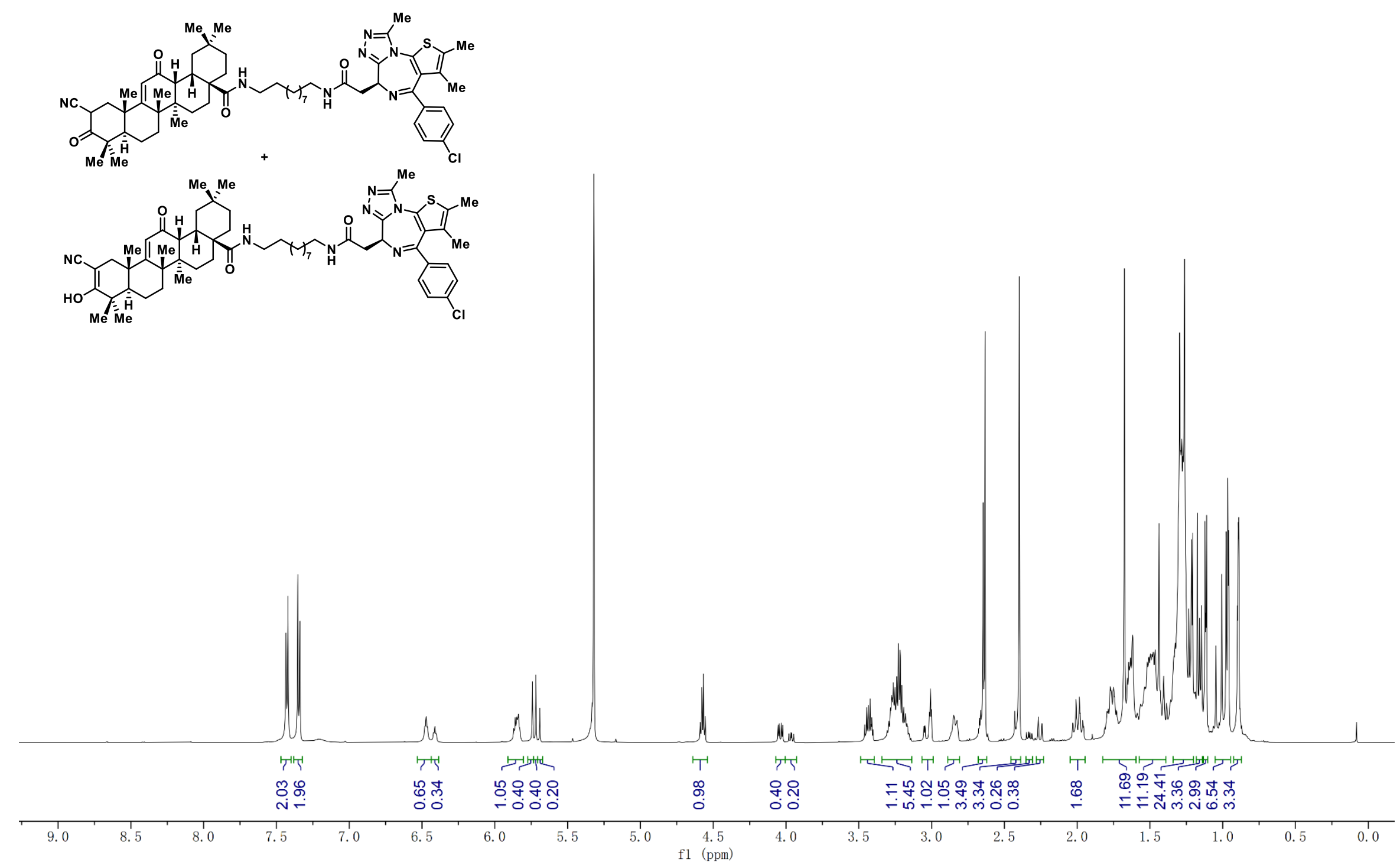


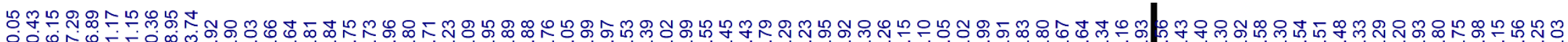

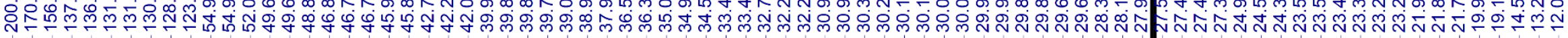
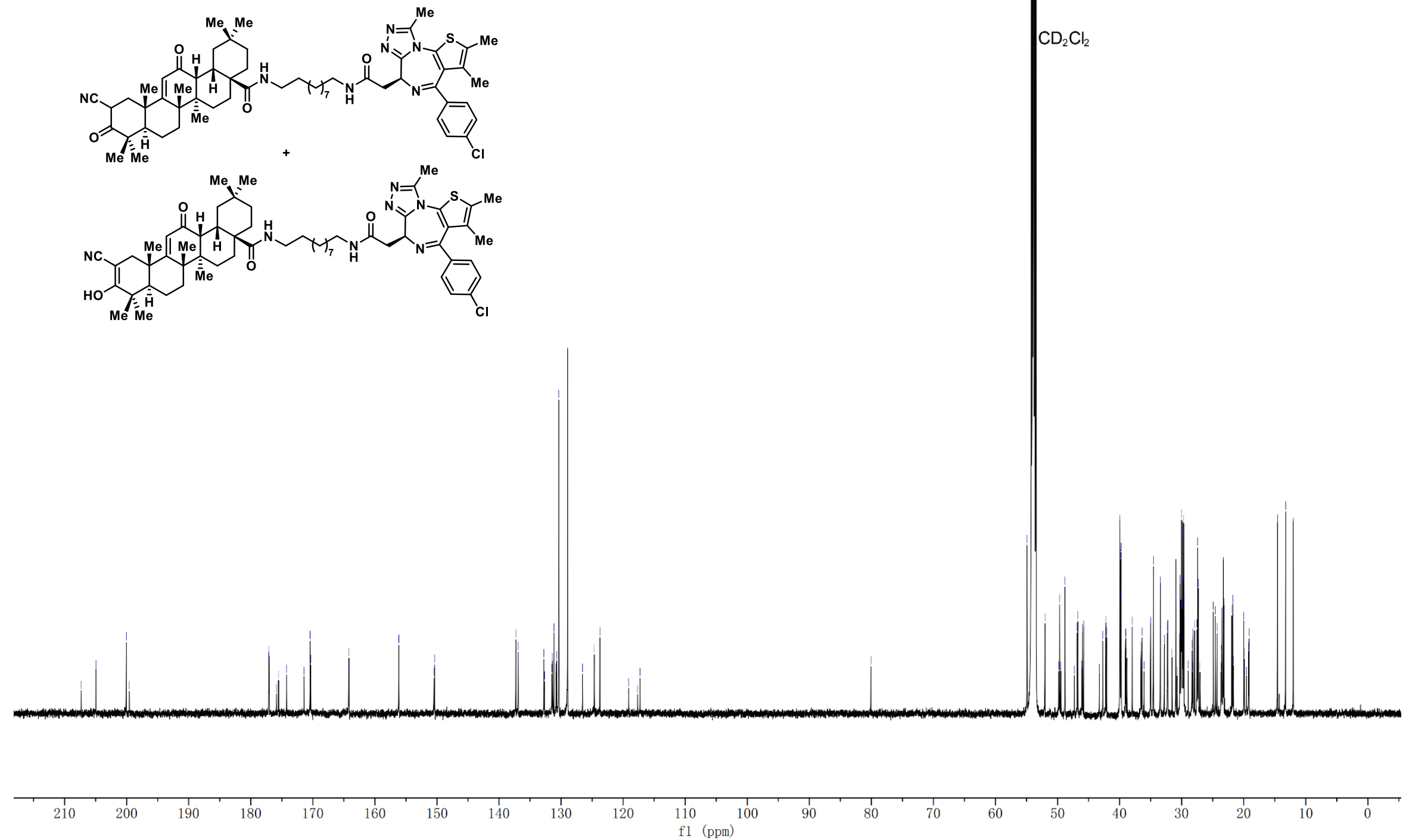


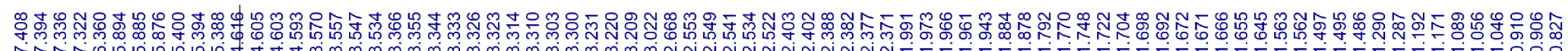
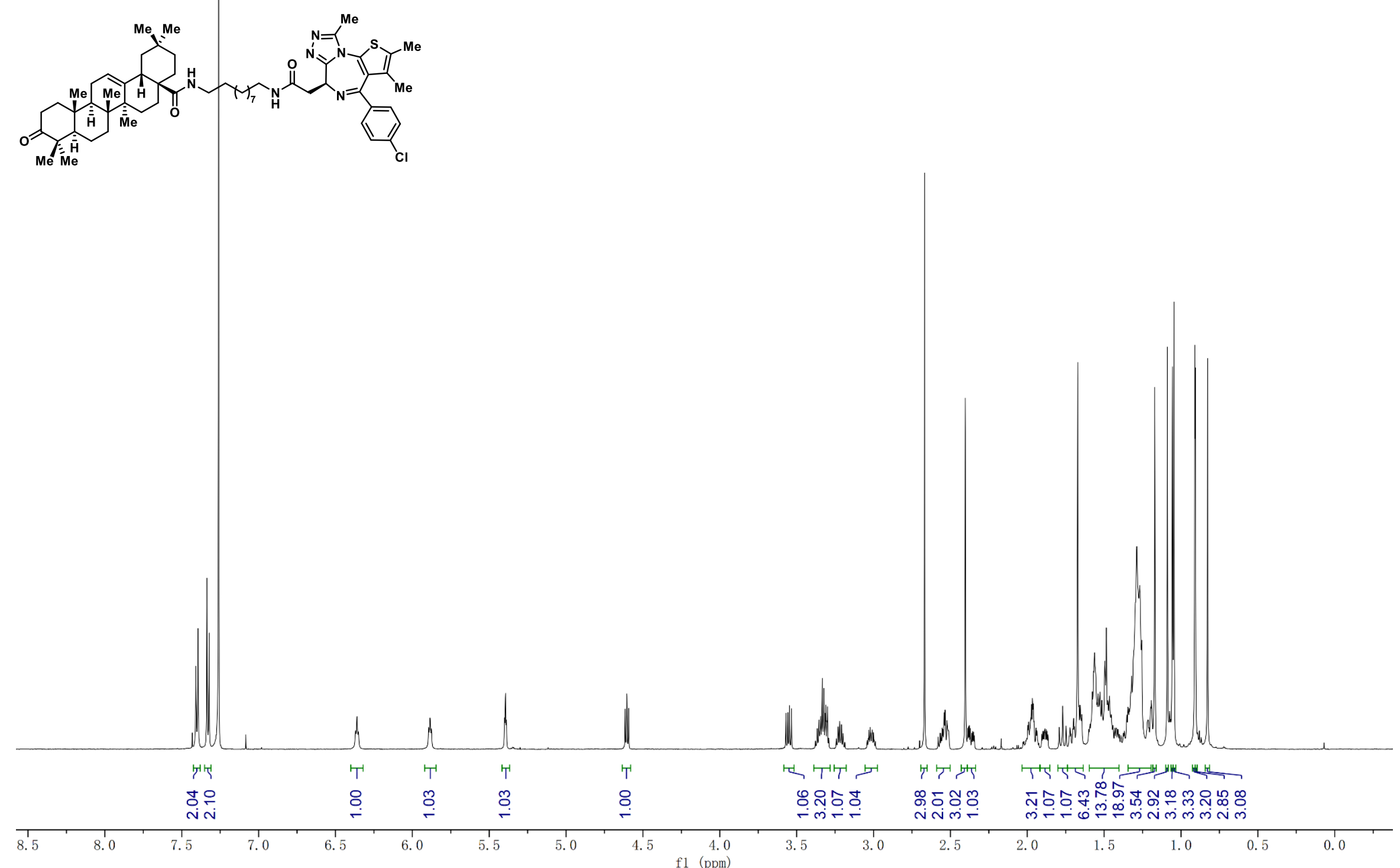


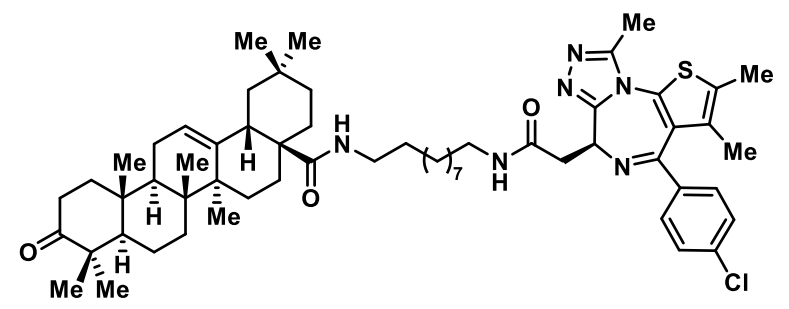
(1)

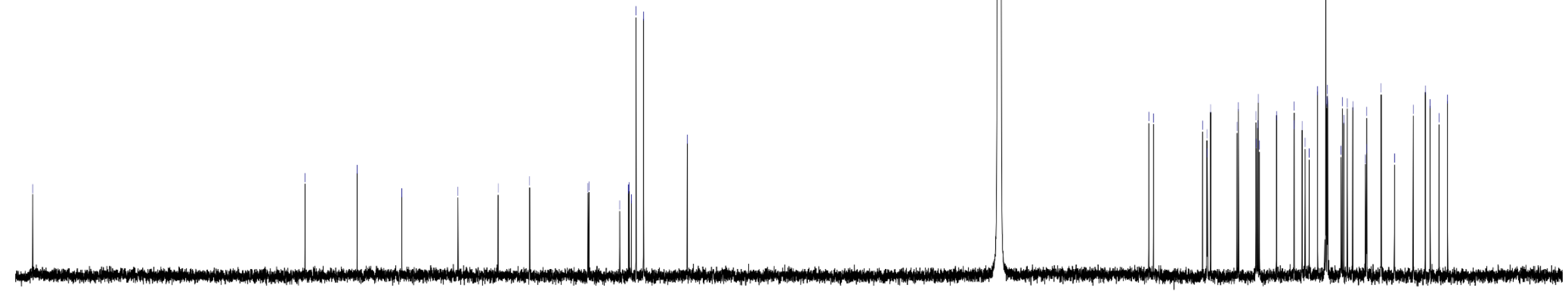

